\title{
COUNSELLING GUIDANCE IN ISLAMIC BOARDING SCHOOL: PROBLEM SOLUTION TO STUDENTS' PERSONALITY [Case Study in Islamic Boarding School Kertosono East Java]
}

\author{
Fitri Aulia \\ Guidance and Counselling Study Program \\ Hamzanwadi University East Lombok NTB \\ e-mail: Fitriaulia04@gmail.com
}

\begin{abstract}
Abstrak
Penelitian ini berusaha membuka wacana tentang ketersediaan layanan bimbingan dan konseling di Pesantren, yang dalam hal ini mengambil focus pada santri MTs/SMP baik putra maupun putri di Pesantren Ar-Raudhotul Ilmiah di Kertosono Nganjuk Jawa Timur. Penelitian ini juga berusaha menguji KCMS, sebuah alat non tes BK yang disusun untuk remaja di Pesantren. Dengan tingkat kesalahan 5\% maka ditemukan sampel sebanyak 142 santri. Berdasarkan hasil analisis dengan SPSS versi 16 dengan analisis faktor, diperoleh Faktor 1 meliputi: (a) Masalah motivasi belajar sebesar 77,3\%, (b) Masalah prisos sebesar 74,5\% (c) Masalah ibadah akhlaq sebesar 66,0\%, (d) Masalah keuangan sebesar 64,8\%, (e) Masalah waktu luang sebesar 59,7\%, (f) Masalah lawan jenis sebesar 59,6\%. Sedangkan Faktor 2 meliputi: (a) Masalah kesehatan jasmani sebesar $86,9 \%$, (b) Masalah teknologi sebesar 69,1\%, dan (c) Masalah keluarga sebesar $41,6 \%$. Tingkat keajegan masalah ini berfungsi sebagai panduan dalam menentukan penanganan yang tepat. Dan akan lebih baik jika penanganan dilakukan langsung oleh tenaga BK agar tercapai hasil yang maksimal.
\end{abstract}

\section{Kata Kunci:}

Bimbingan, Konseling, Pesantren, Kepribadian, Santri 


\begin{abstract}
This study tried to open discourse about the availability of guidance and counseling services in the Islamic boarding school, which in this case takes the focus on students of MTs /SMP both are sons and daughters at Islamic Boarding school of Ar-Raudhotul Ilmiah Nganjuk Kertosono of East Java. This research also tried to examine the KCMS, it is a non-test equipment the Guidance and Counseling that arranged for teenagers at Islamic boarding school. Population there were 235 students. Sampel classes VIII and IX MTs sons and daughters. With an error rate of $5 \%$ then found the sample of 142 students. Based on the analysis with SPSS version 16 with factor analysis, derived factor 1 include: (a) the problem learning motivation about $77.3 \%$, (b) $74.5 \%$ social personality problems (c) Problem $66.0 \%$ of religious morality problems, (d) Finance problems about $64.8 \%$, (e) The problem of leisure time about $59.7 \%$, (f) The issue of the opposite sex about $59.6 \%$. Whereas Factor 2 include: (a) physical health problems about $86.9 \%$, (b) technological problems about $69.1 \%$, and (c) Problem families about $41.6 \%$. The rate constancy of this issue serves as a guide in determining the appropriate response. And it would be better if the handling is done directly by the expert of guidance and counseling in order to achieve maximum results.
\end{abstract}

\title{
Key Word:
}

Guidance, Counseling, Personality, Students 


\section{A. Introductiom}

Basically, the main ideals of guidance and counselling support the goal of Islamic boarding school to prepare Muslim generation become insan kamil. those ideals are (1) to assist in developing a person' personality quality, (2) to help and to develop indovidual mental health quality, (3) to help in developing more effective attitude, and (4) to help an individual to be more independent in life.

Student teenagers are Muslim generation who deserve to gain the best accompanying so they may grow as strong leaders in the future. Strong in personality, emotion, social, capable in religion knowledge and other aspect regard to islamic teaching. Teenager students accompanying will become the responsibility of a lot of people, family is the first side as a education main actor. The second side is all the board of islamic boarding school, the ulemas, teachers, the students, and all people who live in the islamic boarding school, along with the government and society as the third side.

Kepner and Tregoe define problem as a deviation of certain performance standard. Mc Crimon and Taylor define problem as the gap between the present situation and the ideal situation. ${ }^{29}$ Morgan state that problem is various deviation out of unclear situation. ${ }^{30}$

The teenagers' growth are often interfered with various problems, among others are (1) the problem of physic growth, (2) problem between teenagers and parents, (3) problems of school achievement, (4) teenagers' problem with female and male fellows, (5) pronblems related to the definition of teenagers, (6) problems related to their future. Based on the previous research, several problems faced by students in modern islamic boarding school are (a) easily tired and bored, (b) lack of religion basic religion knowledge, (c) suffered from certain desease, (d) misss parents' syndrom, (e) obssesed to technology, (f) often sleep

${ }^{29}$ Yuridi Kusuma, Creative Problem Solving (Solo: Rumah Pengetahuan, 2010), 91.

${ }^{30}$ Singgih Gunarsa, Dasar dan Teori Perkembangan Anak (Jakarta: Gunung Mulia, 1997), 113. 
in the classroom, (g) friendship problem, (f) negative imitative culture, (h) relationship with students of opposite sex, (i) stealing problems, (i) different orientation between students and parents, $(k)$ escape from the islamic boarding school kabur dari pesantren, dan (I) past time traumatic. ${ }^{31}$

Another case also happened at Nurul Ummah Islamic Boarding School for girls, based on the research conducted by Eka Rija, that there were several problems experienced by the female students, those are personal problems range from family, friendship, feeling and internal problems, and difficult to take care their self. Second, social problems covered interaction barriers with environment which include friends' interaction, teachers, and the wife of the boarding school owner. Third, problems which include learning problems.Fourth, career problems include difficulties to decide higher education level. Fifth, problems regard with norms or order values such as obligations, suggestions and prohibitions which are established by the Islamic boarding school. ${ }^{32}$

The problem solutions of teenager students at Islamic boarding School so far focus on punishmet to control attitude. Punisment is given after the mistakes occur. In reality, prevention efforts have been done among others by emotion of social control and character building through the study of islamic books, and the examples of graceful attitude from the guidance teachers. At Muhammadiyah Islamic Boarding School, punishment design is divided into some aspects, namely cognitive, physical, and psychological. Cognitive aspect could be found in the punishment for the language breaker, that is to oblige the students memorizing arbaeen hadith. Physical aspect could be obserevd from security violators, those are like standing up in the middle of field, running around the scholl, cleaning teh bathroom and

${ }^{31}$ Fitri Aulia, "KCMS dan Layanan BK Yang Dibutuhan", dalam Tesis (Yogyakarta: Pascasarjana UIN SUKA, 2012), 181.

${ }^{32}$ Eka Rija Mishayati, Kontribusi Pesantren Dalam Membantu Mengatasi Masalahmasalah Santriwati Pondok Pesantren Nurul Ummah Putri Yogyakarta. Tesis: Pascasarjana UIN SUKA, 2013), 150. 
get the head bald. Punishment for physical aspect could be seen by wearing punishment veil with certain colour, being ashamed, labeling negative, as well as social punishment such as being expelled by other students. Furthermore, , the forms of punishment, often forget important points in the teenager students' development like different background, characteristics, physical and mental condition.

Basic assumption of guidance and counselling that, human nature moves individuals sequentially and positively toward self-enhancement. It recognizes there is a force within each of us that makes us belive that we are special and there is nobody like us. It also assumes that our individual potentials are valuable assest to society and the future of humanity. ${ }^{33}$

Guidance and counselling tries to find out a proper way to respond each problem of teenager students, which are summarized in guidance and counselling service format at Islamic Boarding School. The service focusses on development aspects of teenager students, and applies guidance and couselling principles found in various establishment activities. Nowadays, Islamic boarding schools grow rapidly and types of islamic boarding schools will influence the students' problem characteristics. Therefore, to overcome the problem, an appropriate and wise solution is badly needed so we could produce strong personality students.

KCMS is a non test instrument of guidance and counselling which has been invented after a long research at a modern islamic boarding school in Yogyakarta by the beginning of 2014. This research found a great number of main problems faced by students of junior high schools. Every problem was developed into statement points which were retested to measure the problem stability through a range of validity and reliability process. Then, the questionnaire will be reused in another islamic boarding school in Nganjuk, East Java to know the students' problems among Khalaf (modern) islamic boarding school

\footnotetext{
${ }^{33}$ Daniel T. Sciarra, School Counseling (USA: Thomson Learning. 2004), 9.
} 
types although with several uniqueness. As a non test instrument, KCMS has been equipped by calculation guidnace which is done by SPSS program. Later, calculation result obtained will be interpreted into guidance and conselling service need, which is already provided in KCMS. ${ }^{34}$

\section{B. Research Method}

This research applied quantitative approach, conducted at Modern Islamic Boarding School Ar-Raudhotul Ilmiah Kertosono Nganjuk. Based on teh obtained data, the population was 235 students which consisted of the eighth and the ninth year of junior high school students both male and female. By level of significance $5 \%$, the measureable sample as many as 142 was found. ${ }^{35}$

As the next step, sample calculation was given in detail into each class level and sex. The following was the detail of the number of sample:

1. The male students of the eighth grade $=30$ students

2. Female students of VIII grade $=35$ students

3. Male students of IX grade $=34$ students

4. Female students of IX grade $=43$ students Total number $=142$ students

\section{Ar-Raudhotul Ilmiah Islamic Boarding School and Students' Condition at A Glance}

Foundation of Taman Pengetahuan (YTP or Arraudlatul Ilmiyah) Islamic Boarding School was built by KH Nur Salim Achyar in 1949 in Kertosono Nganjuk East Java. After he passed away, the leadership was held by KH Mustain Kastam. At present, the boading school which located by the eastern part of market no 20 Kertosono is leading by $\mathrm{KH}$ Ali Manshur Kastam.

\footnotetext{
${ }^{34}$ Aulia, KCMS ..., 72.

${ }^{35}$ Sugiyono, Metode Penelitian Pendekatan Kuantitatif (Bandung: Alfabeta, 2008), 46.
} 
There are two levels of organization management in this islamic boarding school. The first level is among the teachers, while the second level is among the students. The students of the twelfth grade who become the daily board, and who interact directly with the whole students. The Islamic boarding school organization among the students consist of several parts as follow:

1. The chairman of the school

2. The vice chairman of the school

3. The first secretary

4. The second secretary

5. The first treasurer

6. The second treasurer

7. Security coordinator

8. Vice of security

9. Worship coordinator

10. Cleanness Coordinator

11. Health Coordiantor

12.Language Coordinator

13.Equipment coordiantor

Each of the position above, has different duties based on its main task and function. Worship coordinator has a duty to control and observe the schedule of pray, recitation of the holy Qur'an, and the real daily worship. While, health coordinator's duty is to control and take care students who suffer from certain deseases. The unwell student will report to his or her own room chairman, to propose medical treatment in the hospital or local health clinic. Health coordinator along with a team will arrange the schedule of students who will accompany their sick fellow to have a health treatment. Several deseases caught by students are influenza, cough, fever, skin desease, smallpox and sultry. 
Language coordinator's duty is to create development in language. Languages developed at islamic boarding school are English and Arabic. Whereas, equipment coordinator has a duty to manage public facility, such as the trouble of electricity current, this boarding school used the Arabic and English language. The equipment coordinator must be manage general facilities, like a electric problems, damage in bathroom and damage in other public facility.

It is a fact that generally students have similar complain, that is the limited information access. Students are only allowed to listen radio once a week from Thursday evening to Friday afternoon at $5 \mathrm{pm}$. As information access, radio is alsoan entertainment device fro the students. Most of them do not only listen news program but also enjoy music from certain radio waves.

Apart from music as entertainment and other programs from the radio station, students are also allowed to leave the boarding school for taking a walk or going to shop basic needs to nearly market or shops. The boarding school location is only 100 meter from the Banaran village market provides benefits to the students, to the board, and the nursemaid as well.

An advantage for the boards and nursemaid is the ease to monitor the students when they are in outside of the school environment. This is also confessed by a number of shopkeepers who know the school board well, so they are also so cooperative to monitor the students. They wear uniform with specific colour which can ease the society to differ them from students from other schools.

The rule which allows students to visit market is also strengthened by the rule of location border which students could visit though there are still some students disobey and break the rule.

This kind of rule break is categorized into the low one, and the punishment is also easy. The violation will get hard when it is followed by a randezvous of the opposite sex, either the stuedents inside the boarding school or teenagers outside the boarding school. Once, it 
happened to one of the female students who made a date with her opposite sex in one of the shops. Students who committed fatal violation will be punished by wearing red headscarf written "The breaker of school rule" for a week. Meanwhile, other breaks are categorized into middle violation, that is sending letter to the opposite sex, and using mobile phone. The punishment which must be fulfilled by wearing red headscarf for two days.

Low violation are, late to go to school due to reluctance, late to attend an islamic preach, late for pray, language break, andrproducing rude words. Punishment for this kind of being warned and giving breaking point recorded in a punishment book. Then, one day if the students break the same rule again, they will be punished in higher level.

Indeed, the significance of spare time for students is very urgent. The various activities of the islamic boarding school, both daily routine at school, the schedule of general school, and religion schedule often cause bored and stree of students.

The Curriculum Is In Ponpes Consists Of:

\begin{tabular}{|l|l|l|l|l|l|}
\hline 1. & Matematika & 9. & Bahasa Arab & 17. & IPS \\
\hline 2. & Fisika & 10. & Bahasa Inggris & 18. & Akhlaq \\
\hline 3. & Biologi & 11. & $\begin{array}{l}\text { Bahasa } \\
\text { Indonesia }\end{array}$ & 19. & BK \\
\hline 4. & PKN & 12. & TIK & 20. & Nahwu \\
\hline 5. & Fiqih & 13. & Hadits & 21. & Shorof \\
\hline 6. & Qur'an hadits & 14. & Tahsin & 22. & Qur'an Hadits \\
\hline 7. & Aqidah Akhlaq & 15. & Qiroatul Kutub & 23 & Tafsir \\
\hline 8. & $\begin{array}{l}\text { Sejarah } \\
\text { Kebudayaan Islam }\end{array}$ & 16. & $\begin{array}{l}\text { Bahasa } \\
\text { Daerah }\end{array}$ & & \\
\hline
\end{tabular}

List Of Religious Subjects Consist Of:

\begin{tabular}{|l|l|l|l|}
\hline 1. & Nahwu & 5. & Conversation \\
\hline 2. & Shorof & 6. & Tahsin \\
\hline 3. & Tarikh Islam & 7. & Muhadatsah \\
\hline 4. & Ushul fiqih & 8. & Akhlaq \\
\hline
\end{tabular}


The Reference Book Learn About Religion:

\begin{tabular}{|c|c|}
\hline 1. & Bulughul Maram \\
\hline 2. & Tafsir al qur'an \\
\hline 3. & Hadits Riyadush Sholihin \\
\hline 4. & Muhktar \\
\hline 5. & Hadits arba'in \\
\hline 6. & Nahwu \\
\hline 7. & Shorof \\
\hline
\end{tabular}

\section{Students' Problem Based on KCMS Calculation}

After filling KCMS to students at Ar-Raudhotul Ilmiah Islamic boarding school, analysis result by using factor analysis was:

Factor Analysis Assumption Test Result

$\mathrm{KMO}$ and Bartlett>s Test

\begin{tabular}{|l|l|l|}
\hline \multicolumn{2}{|l|}{ Kaiser-Meyer-Olkin Measure of Sampling Adequacy. } & .844 \\
\hline Bartlett>s Test of Sphericity & $\begin{array}{l}\text { Approx. Chi- } \\
\text { Square }\end{array}$ & 450.892 \\
\hline & Df & 36 \\
\hline & Sig. & .000 \\
\hline
\end{tabular}

Based on the data above, KMO score gained was 0,844 which showed > from 0,5, whereas significant level was 0,000 yang menunjukkan $<0,05$. By the result so factor analysis calculation process in KCMS has fulfill the condition for factor analysis test. The next procedure to do was searching MSA score (Measure Of Sampling Adequacy). In order to continue the analysis, MSA minimum score must be $>0,5$ so the variable which will be examined could be predicted and analyzed. ${ }^{36}$

In the column Anti-Image Correlation, MSA score will be marked by score $\left({ }^{a}\right)$, and the following result was gained:

1. Social Personal Problem : $0,820>0,5$

2. Learning Motivation Problem : 0,802 >0,5

36Santoso, Buku...., 13. 
3. Financial Problem

4. Technological Problem

5. Family Problem

6. Worship and Moral problem : 0,912 >0,5

7. Physical Health Problem

8. Opposite sex problem

9. Spare tiem problem

$$
\text { : } 0,899>0,5
$$$$
: 0,801>0,5
$$$$
: 0,837>0,5
$$

$: 0,782>0,5$

$: 0,923>0,5$

$: 0,875>0,5$

Based on the MSA score above, so the whole variable could be analyzed further since each score was $>0,5$

\section{Loading Factor}

Having determined that the maximum factor which could be formed was 2 , then each variable grouping was done, whether it is in factor 1 or factor 2. To determine it, we can check in the following Rotate Component Matrix table:

\begin{tabular}{|l|c|c|}
\hline \multicolumn{3}{|c|}{ Rotated Component Matrix } \\
\hline \multirow{2}{*}{} & \multicolumn{2}{|c|}{ Component } \\
\cline { 2 - 3 } & 1 & 2 \\
\hline Social personal problem & 2.745 & .480 \\
\hline Learning motivation problem & 1.773 & .251 \\
\hline Financial problem & 4.648 & .420 \\
\hline Technological problem & .277 & 2.691 \\
\hline Family problem & .332 & 3.416 \\
\hline Worship and moral problem & 3.660 & -.097 \\
\hline Physical health problem & -.028 & 1.869 \\
\hline Opposite sex problem & 6.596 & .178 \\
\hline Spare time problem & 5.597 & .448 \\
\hline Extraction Method: Principal Component Analysis. \\
\hline Rotation Method: Varimax with Kaiser Normalization. \\
\hline a. Rotation converged in 3 iterations. \\
\hline
\end{tabular}


Based on the table above, variable which is appropriate to factor 1 and factor 2 could be seen through the correlation between variable and factor, that is the greater score between factor. Thus, the items of factor and variable are:

\begin{tabular}{|c|l|c|}
\hline Factor & \multicolumn{1}{|c|}{ Problem Variable } & Percentage \\
\hline \multirow{4}{*}{1} & Learning motivation problem & $773 \%$ \\
\cline { 2 - 3 } & Social personal problem & $745 \%$ \\
\cline { 2 - 3 } & Worship and moral problem & $660 \%$ \\
\cline { 2 - 3 } & Financial problem & $648 \%$ \\
\cline { 2 - 3 } & Spare time problem & $597 \%$ \\
\cline { 2 - 3 } & Opposite sex problem & $596 \%$ \\
\hline \multirow{3}{*}{2} & Physical health problem & $869 \%$ \\
\cline { 2 - 3 } & Technological problem & $691 \%$ \\
\cline { 2 - 3 } & Family problem & $416 \%$ \\
\hline
\end{tabular}

From the illustration above, it is found that problem percentage which affected students' was the problem with the biggest percentage was learning motivation, while the least problem faced by the students was family problem. The next step was to observe gudnace and counselling service needed by the students at Ar-Raudhotul Ilmiah islamic boarding school Kertosono.

\section{E. Guidance and Counselling Service Recommendation Needed by Students}

1. Orientation Service and Information

Orientation service is generally applied at the early time when the students live in islamic boarding school environment, while information service are offered continously ${ }^{37}$ during the students live in islamic boarding school. The types of service in each problem are:

${ }^{37}$ Hibana S. Rahman, Bimbingan dan Konseling Pola 17 (Yogyakarta: UCY Press, 2003), 45. 
a. Study Problem, this problem could be conveyed through a course about certain target and curriculum owned by islamic boarding school for the students, several supporting programs and infrastructure prepared by the schools.

b. Social and Personal Problems, it is basically interrelated to moral. This problem has to do with causal and effeat law from response or students' morality, this discussion also develops into more privacy matters, such as students' personal experience, emotion, traumatic, personal experience intrapersonal and interpersonal.

c. Moral problem, it can be resumed into specific rules such as a) organized rules and b) unorganized rules. Organized rules are to spread school rules from the obligations, prohibition and punishment. Unorganized rules include to give understanding the culture, or norms in society.

d. Financial problem, it is summarized in financial management matters at islamic boarding schools: 1) the significance of saving program, b) the engative effect of being extravagant, c) purchasing trivial stuffs include some internal school programs on financial management.

e. Spare time problem, this matter could be conveyed well through the students management time. It includes program prepared to facilitate activity in the spare time.

f. Opposite sex problem, this point has to do with moral and social personal which have been explained previously, so to achieve the maximum result, this course could be conveyed respectively after the two matters.

g. Physical Health Problem. Physical problem deals with the clean environment at the school, range from the dormitory, personal 
stuffs which can pass on bacteria, low quality of sanitation and other public facilities have to do with health.

h. Technological problem. Technology has its own virtues and weaknesses toward the students' life in islamic boarding school.

i. Family problem. Solution about this problem could be done by understanding the students' ambition and parents' orientation. Orientation service on this problem could involve parents in specific service so they will make the students independent.

2. Students' studying guidance service

This service could be done gradually by the following steps: a) introducing the students to the islamic boarding school curriculum, both the islamic and the general school curriculum, b) understanding students who experience varioys study problems, either lessons at school or religion lesson, c) revealing the problem sources of learning problem of students, and d) offering solution to solve students' learning problems. $^{38}$

\section{Individual counselling service}

This service could be in the forms of prevention, curative, and development at islamic boarding schools. The prevention is intended for more complicated problem prevention.

Basically, the nine problems found among the students at MBS junior high school are representative enough if it is handled by individual counseeling individual moreover problems with opposite sex, learning problem, and social personal problem. Sometimes, individual counselling alone is not sufficient to assist the students solve their problems and other services such as group guidance and group conselling are needed.

4. Group guidance service

\footnotetext{
${ }^{38}$ Aulia, KCMS ..., 56.
} 
This kind of guidance is very representative to cope every problems, among others financial problems by inviting enterpreneur or sharia economics experts to offer guidance about the significance of thrift life and manage the students' financial. To solve physical problems by inviting local health department to have a guidance about the importance of clean life and health in school environment. Other proper things are learning problems, social and personal, and spare time, one of them by inviting expert motivators to convey lecture about the significance of having life target, motivation as islamic boarding school students, and positive ideas about life as an individual and social people.

\section{F. Conclusion}

Based on the research conducted through KCMS filling at Raudhotul Ilmiah Islamic Boarding School Kertoson, a number of students' personality problems as well as their stability level. Among the nine problem aspects, different approach and solutions are needed. Guidance and counselling bring chance to provide solutions in some kinds of services, among others are study guidance, orientation serviceand information, individual conselling service and group guidance service.

Based on the result present research, guidance and counselling service are very urgent to be found in islamic boarding schools, regarding the fact that the existence isn still less, whereas the problems of students' personality will always happen all their life. 


\section{References}

Aulia, Fitri, "KCMS dan Layanan BK Yang dibutuhan", Tesis (Yogyakarta: Pascasarjana UIN SUKA, 2012)

Gunarsa, Singgih, Dasar dan Teori Perkembangan Anak (Jakarta: Gunung Mulia, 1997)

Mishayati, Eka Rija, "Kontribusi Pesantren Dalam Membantu Mengatasi Masalah-masalah Santriwati Pondok Pesantren Nurul Ummah Putri Yogyakarta", Tesis (Yogyakarta: Pascasarjana UIN SUKA, 2013)

Yuridi, Creative Problem Solving (Solo: Rumah Pengetahuan, 2010)

Rahman, Hibana S, Bimbingan dan Konseling Pola 17 (Yogyakarta: UCY Press, 2003)

Santoso, Buku Latihan SPSS Statistik Multivariat (Jakarta: Gramedia, 2003)

Sciarra, Daniel T, School Counseling (USA: Thomson Learning, 2004)

Sugiyono, Metode Penelitian Pendekatan Kuantitatif (Bandung: Alfabeta, 2008) 